\title{
Geographic Pattern of Sushi Product Misdescription in Italy-A Crosstalk between Citizen Science and DNA Barcoding
}

\author{
Anna Maria Pappalardo *, Alessandra Raffa, Giada Santa Calogero and Venera Ferrito
}

check for

updates

Citation: Pappalardo, A.M.; Raffa, A.; Calogero, G.S.; Ferrito, V. Geographic Pattern of Sushi Product Misdescription in Italy-A Crosstalk between Citizen Science and DNA Barcoding. Foods 2021, 10, 756. https://doi.org/10.3390/foods10040756

Academic Editors:

Margit Cichna-Markl and

Isabel Mafra

Received: 16 February 2021

Accepted: 27 March 2021

Published: 2 April 2021

Publisher's Note: MDPI stays neutral with regard to jurisdictional claims in published maps and institutional affiliations.

Copyright: (c) 2021 by the authors. Licensee MDPI, Basel, Switzerland. This article is an open access article distributed under the terms and conditions of the Creative Commons Attribution (CC BY) license (https:/ / creativecommons.org/licenses/by/ $4.0 /)$.
Department of Biological, Geological and Environmental Sciences, Section of Animal Biology "M. La Greca", University of Catania, Via Androne 81, 95124 Catania, Italy; alessandra.raffa92@gmail.com (A.R.); giadacalogero@gmail.com (G.S.C.); vferrito@unict.it (V.F.)

* Correspondence: pappalam@unict.it; Tel.: + 39-095-730-6051

\begin{abstract}
The food safety of sushi and the health of consumers are currently of high concern for food safety agencies across the world due to the globally widespread consumption of these products. The microbiological and toxicological risks derived from the consumption of raw fish and seafood have been highlighted worldwide, while the practice of species substitution in sushi products has attracted the interest of researchers more than food safety agencies. In this study, samples of sushi were processed for species authentication using the Cytochrome Oxidase I (COI) gene as a DNA barcode. The approach of Citizen Science was used to obtain the sushi samples by involving people from eighteen different Italian cities (Northern, Central and Southern Italy). The results indicate that a considerable rate of species substitution exists with a percentage of misdescription ranging from $31.8 \%$ in Northern Italy to $40 \%$ in Central Italy. The species most affected by replacement was Thunnus thynnus followed by the flying fish roe substituted by eggs of Mallotus villosus. These results indicate that a standardization of fish market names should be realized at the international level and that the indication of the scientific names of species should be mandatory for all products of the seafood supply chain.
\end{abstract}

Keywords: sushi restaurants; COI barcoding; molecular traceability; teleosts

\section{Introduction}

In part I of Food Business Regulation (Cap. 132X) of the Government of the Hong Kong Special Administrative Region, the meanings of the terms sushi and sashimi are made explicit. In particular, sushi is described as "food consisting of cooked and pressed rice flavoured with vinegar and garnished with other food ingredients including raw or cooked or vinegared seafood, marine fish or shellfish roe, vegetable, cooked meat or egg on top or in the middle which may or may not be wrapped with seaweed and usually served in pieces", while sashimi is described as "food consisting of fillets of marine fish, molluscs, crustaceans, fish roe or other seafood to be eaten in raw state". Although sushi and sashimi are perceived by consumers as healthy foods, the biological and chemical hazards for human health, derived from the consumption of raw fish and seafood, have been highlighted worldwide, such as the risk of parasitic and/or pathogenic microorganism infection [1-7]; the potential risk arising from a lack of proper control of temperature of these perishable foods [8]; the risk of exposure to toxicants, such as heavy metals and polychlorinated biphenyls (PCBs); polycyclic aromatic hydrocarbons (PAHs) and other contaminants $[4,7,9,10]$. The food safety of sushi and sashimi and the health of consumers are currently of high concern given that the consumption of these products is now globally widespread [11,12]. As a result, the most important food safety agencies in the world, such as the European Food Safety Authority [13], the Food and Drug Administration [14], the Hong Kong Food and Environmental Hygiene Department's and the World Health Organization, have implemented regulations and guidelines to face all issue related to the consumption of raw fish and seafood. In this context, another important issue that 
has attracted the interest of researchers is the molecular authentication of fish and seafood species in transformed products, because the processing procedure generally removes the specific diagnostic morphological traits useful to assign the product to a particular species through only morphological inspection. Indeed, the voluntary or involuntary practices of substitution of valuable species with species of less value for economic profit have been detected worldwide in the last decades by using DNA sequencing, which proved to be the most useful method to unveil these frauds. For example, DNA-based surveys carried out in European and non-European countries have highlighted a high rate of food frauds in the fishery sector [15-18]. Among the most used molecular markers, mitochondrial genes, such as Cytochrome b (Cytb), 16S rRNA (16S), Cytochrome Oxidase I (COI) and mtDNA Control Region (CR), have proven to be optimal tools for seafood species authentication. However, while the CR and Cytb have been successfully and widely used to study the genetic population structure [19-26] rather than to authenticate fish species [27-29], COI has become the optimal DNA barcode for the identification of animal species [30-35] and particularly for fish species authentication in seafood products [15,36-41]. Furthermore, researchers have been also encouraged to look for rapid and low-cost molecular strategies to tackle substitution species frauds by large scale screening both using classic and new technologies [42-49]. COI DNA barcoding has been used to unveil the misdescription of sushi products in the United States of America [50], the United Kingdom [11], South-Korea [17], Malaysia [51,52] and Canada [53]. In Italy, the study by Armani et al. [54] performed a molecular-based authentication of the seafood species used in sushi preparations in four provinces of Tuscany. However, when designing a food fraud investigation, the sampling plan is pivotal to ensure that as many products as possible are sampled over a large area. In this context, the contribution of consumers is crucial, and the citizen science (CS) approach, based on involving a large number of people, normally including the local population of a region or a state, with the aim of collecting scientific data, could prove to be of fundamental help. This strategy permits the collection of a vast quantity of data information or samples that cannot be collected by only one researcher or a small research team. The quality of a study is not undermined by the citizen science approach if the work planning includes comprehensible protocols, effective training before starting and accurate oversight during the studying period [55,56]. Based on these premises, in this study, we involved many people from eighteen different cities throughout the Italian territory (North, Central and South Italy) to obtain samples of sushi to be processed for species authentication by using the COI gene as the DNA barcode. To the best of our knowledge, this is the first study on sushi authentication extended to the Italian territory by using the approach of citizen sciences. The aim was to analyze the compliance of the fish names of marketed products with the list of Italian names of fish species of commercial interest included in the Italian Ministerial Decree (MD) n.19105 22 September 2017 of the Italian Ministry of Agricultural, Food and Forestry Policies and then to verify if the information the consumers obtain from the menu meet the transparency requirements established by the European regulations.

\section{Materials and Methods}

\subsection{Sample Collection and Survey}

Between January 2018 and January 2019, we collected sushi products sold in restaurants and takeaways in different cities of Northern, Central and Southern Italy (Figure 1). Samples were obtained using a "citizen science" strategy involving people who responded to the invitation to participate in the "sushi survey". People living in various Italian regions were chosen among relatives and friends of our research team and colleagues at the University of Catania. This allowed us to establish a direct contact with them to better program the sampling. Prior to the start of the study, people received a letter from us where we explained our research project and asked them about their willingness to participate. After receiving their consent, we contacted them by phone and also via skype (i) to respond to all queries they would ask us; (ii) to explain how to proceed for sampling sushi products; 
and (iii) how to fill in the documents that they would receive by us. In particular, we advised them to focus the sampling on white fish, tuna and eggs. By mail, we provided participants with a step-by-step guide for sampling, including a sample collection table (Figure S1: sushi sampling guide) together with a $1.5 \mathrm{~mL}$ eppendorf tube to be used to preserve small pieces of sampled sushi in $95 \%$ ethanol. A stamped envelope to be used to send us the samples and the collection table was also included. In the table, participants indicated the sushi venue (restaurant or takeaway) they visited; the name on the menu of the product they consumed; and how many samples among white fish, tuna and/or eggs they collected.

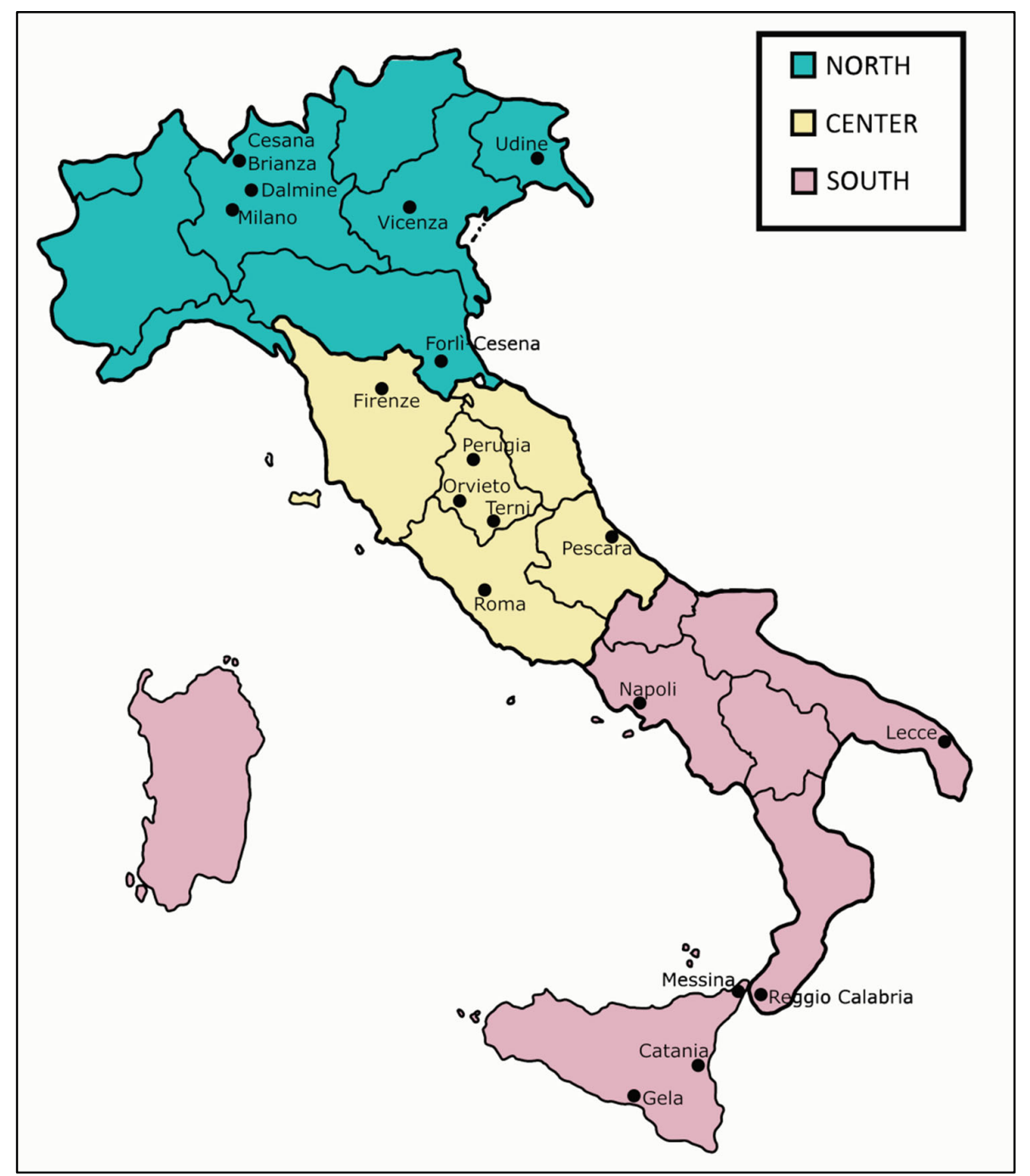

Figure 1. Collection sites of the sushi survey in Northern (green), Central (light yellow) and Southern (pink) Italy.

\subsection{DNA Barcoding Analysis}

A total of 180 samples were processed for DNA analysis. For each sushi product, 3 DNA extractions were replicated to investigate the presence of multiple fish species in the product. Total genomic DNA was extracted using a DNeasy tissue kit (Qiagen, Hilden, Germany) following the manufacturer's instructions and with some modifications. DNA concentration was measured with a NanoDrop One spectrophotometer (Thermo Scientific, Waltham, MA, USA). A portion of about 650 bases of the COI gene was amplified following the Polymerase Chain Reaction (PCR) conditions reported by [38] in a $50 \mu \mathrm{L}$ reaction mixture also containing the M13 tailed primers (VF2_t1 and FishR2_t1) described 
in Ivanova et al. [57] to improve the sequencing quality of the PCR products. Negative controls were included in all PCR runs to check for cross-contamination. Amplicons successfully obtained were verified by electrophoresis on a $0.8 \%$ agarose gel and displayed through a Safe Imager TM 2.0 Blue Light Transilluminator (Thermo Fisher, Waltham, MA, USA) using the SYBR ${ }^{\circledR}$ Safe dye (Thermo Fisher, Waltham, MA USA). The QIAquick PCR purification kit (Qiagen, Hilden, Germany) was used to purify all amplicons, which were then bidirectionally sequenced with M13 sequencing primers using an ABI 3730 automated sequencing machine at Genechron Biotech Company (https: / www.genechron. com accessed on 30 January 2021).

\subsection{Data Analysis}

The chromatograms were checked for the quality of peaks and assembled using ChromasPro 2.6.6 software (https:/ / technelysium.com.au/wp/chromaspro/ accessed on 30 January 2021). Barcode multiple-sequence alignment was carried out using the online version of MAFFT v.7 [58]. Sequences were trimmed when the errors occurred near the beginning and again at the end of any sequence. Primer sequences were manually removed by using BioEdit 7.2 (https: / / bioedit.software.informer.com/versions / accessed on 30 January 2021). The obtained sequences were carefully checked for the presence of nuclear mitochondrial pseudogenes or nuclear mitochondrial DNA sequences (NUMTs), which could be easily coamplified with orthologous mtDNA sequences [59]. The translation of nucleotide sequences to amino acids was performed by the EMBOSS Transeq tool (https:/ / www.ebi. ac.uk/Tools/st/emboss_transeq accessed on 30 January 2021January) in order to check for premature stop codons and to verify that the open reading frames were maintained in the protein-coding locus. To confirm the identity of the amplified sequences, we conducted Basic Local Alignment Searches (BLAST) (https:/ /blast.ncbi.nlm.nih.gov accessed on 30 January 2021) against GenBank without "Uncultured/environmental sample sequences" with megablast and default parameters (https: / /www.ncbi.nlm.nih.gov/genbank/ accessed on 30 January 2021) and also used the BOLD database (https:/ / www.boldsystems.org/ accessed on 30 January 2021) to validate our sequences. For species assignment, the highest values of percent identity found between the query sequence and the BLAST matched sequences were selected. If multiple BLAST matches had identical percent identity values, it was confirmed that all matches belonged to the same species. All sequences obtained from the present study were published in the National Center for Biotechnology Information database (NCBI), and their GenBank accession numbers are reported in Tables 1-3. 
Table 1. Sushi sampling in Northern Italy. In square brackets, the number of processed samples for each sushi product. In bold, misdescription cases.

\begin{tabular}{|c|c|c|c|c|c|c|c|c|}
\hline Code* & Retail Point & $\begin{array}{l}\text { Menu/Label } \\
\text { Description }\end{array}$ & $\begin{array}{l}\text { Scientific Nameof } \\
\text { Declared Species }\end{array}$ & $\begin{array}{c}\text { Identified Species } \\
\text { by DNA } \\
\text { Barcoding and } \\
\text { BLAST Search }\end{array}$ & $\begin{array}{c}\text { GenBank Acc. } \\
\text { Number } \\
\text { of Obtained } \\
\text { Sequences }\end{array}$ & $\begin{array}{c}\text { Matched } \\
\text { GenBank } \\
\text { Accession from } \\
\text { BLAST }^{\circ}\end{array}$ & $\begin{array}{l}\text { Matched } \\
\text { BOLD ID }\end{array}$ & $\begin{array}{l}\% \text { Identity with } \\
100 \% \text { Coverage }\end{array}$ \\
\hline MIL1B [3] & Restaurant & sea bream or common bass & Sparus aurata/Dicentrarchus labrax & Dicentrarchus labrax & MW714726 & KР330301 & GBMIN94166-17 & 99.69 \\
\hline MIL1T [3] & Restaurant & tuna & Thuпnus thynnus & Thunnus albacares & MW714727 & MH638785 & ANGBF54814-19 & 99.54 \\
\hline MIL2B [1] & Takeaway & sea bream or common bass & Sparus aurata/Dicentrarchus labrax & Dicentrarchus labrax & MW714728 & KY176457 & GBMIN121550-17 & 99.37 \\
\hline MIL2T [3] & Takeaway & tuna & Thuпnus thynnus & Thunnus albacares & MW714729 & MH638777 & ANGBF54806-19 & 98.47 \\
\hline MIL3B [3] & Takeaway & sea bream & Sparus aurata/Dicentrarchus labrax & Dicentrarchus labrax & MW714730 & KР330301 & GBMIN94165-17 & 98.74 \\
\hline MIL4B [3] & Takeaway & common bass & Sparus aurata/Dicentrarchus labrax & Sparus aurata & MW714731 & MF438138 & ANGBF45411-19 & 99.54 \\
\hline CES1B [3] & Takeaway & common bass & Dicentrarchus labrax & Dicentrarchus labrax & MW714732 & KP330300 & GBMIN94165-17 & 99.06 \\
\hline DAL1T [3] & Restaurant & tuna & Thunnus thynnus & Thunnus albacares & MW714734 & MH638785 & ANGBF54814-19 & 99.24 \\
\hline DAL1E [3] & Restaurant & tobiko/flying fish egg & Hirundichthys affinis ${ }^{\circ}$ & Hirundichthys oxycephalus & MW714735 & KX769042 & GBMIN125981-17 & 99.02 \\
\hline VI1T [3] & Restaurant & tuna & Thunnus thynnus & Thunnus thynnus & MW714736 & KP975912 & FCSF387-14 & 98.92 \\
\hline VI1B [3] & Restaurant & sea bream & Sparus aurata & Sparus aurata & MW714737 & KC501553 & DNATR1582-13 & 98.78 \\
\hline VI1E [3] & Restaurant & tobiko/flying fish egg & Hirundichthys affinis ${ }^{\circ}$ & Hirundichthys affinis & MW714738 & JQ842898 & TOBA086-09 & 99.52 \\
\hline FC1B [3] & Takeaway & sea bream & Sparus aurata & Seriola lalandi & MW714739 & MH211123 & GBMNA18700-19 & 99.39 \\
\hline FC1T [3] & Takeaway & maguro Yaki (red tuna) & Thunnus thynnus & Thunnus thynnus & MW714740 & KC501694 & DNATR1720-13 & 99.39 \\
\hline FC2B [1] & Takeaway & sea bream & Sparus aurata & Sparus aurata & MW714741 & MF438138 & ANGBF45411-19 & 99.69 \\
\hline UD1B [3] & Restaurant & kajiki roll (swordfish) & Xiphias gladius & Xiphias gladius & MW714742 & MK295657 & ANGBF51916-19 & 99.38 \\
\hline UD1T [2] & Restaurant & tuna & Thunnus thynnus & Thunnus obesus & MW714743 & GU451774 & GBGCA1353-13 & 99.08 \\
\hline
\end{tabular}

* MIL = Milano; CES = Cesena Brianza; DAL = Dalmine; VI = Vicenza; FC = Forlì Cesena; UD = Udine. ${ }^{\circ}$ These species are not present in the Italian D.M. 2008. 
Table 2. Sushi sampling in Central Italy. In square brackets, the number of processed samples for each sushi product. In bold, misdescription cases.

\begin{tabular}{|c|c|c|c|c|c|c|c|c|}
\hline Code * & Retail Point & $\begin{array}{l}\text { Menu/Label } \\
\text { Description }\end{array}$ & $\begin{array}{c}\text { Scientific Name } \\
\text { of Declared Species }\end{array}$ & $\begin{array}{c}\text { Identified Species } \\
\text { by DNA } \\
\text { Barcoding and } \\
\text { BLAST Search }\end{array}$ & $\begin{array}{c}\text { GenBank Acc. } \\
\text { Number } \\
\text { of Obtained } \\
\text { Sequences }\end{array}$ & $\begin{array}{c}\text { Matched } \\
\text { GenBank } \\
\text { Accession from } \\
\text { BLAST }^{\circ}\end{array}$ & $\begin{array}{l}\text { Matched } \\
\text { BOLD ID }\end{array}$ & $\begin{array}{l}\% \text { Identity with } \\
100 \% \text { Coverage }\end{array}$ \\
\hline FIR1B [3] & Takeaway & common bass & Dicentrarchus labrax & Dicentrarchus labrax & MW714657 & KР330300 & GBMIN94165-17 & 99.21 \\
\hline FIR1T [3] & Takeaway & tuna & Thunnus thynnus & Thunnus albacares & MW714658 & MH638777 & ANGBF54806-19 & 99.85 \\
\hline FIR1E [3] & Takeaway & tobiko/flying fish egg & Hirundichthys affinis ${ }^{\circ}$ & Hirundichthys affinis & MW714659 & JQ842898 & TOBA9086 & 99.52 \\
\hline PER1B [3] & Restaurant & sea bream or common bass & Sparus aurata/Dicentrarchus labrax & Sparus aurata & MW714660 & MF438138 & ANGBF45411-19 & 99.54 \\
\hline PER1T [3] & Restaurant & tuna & Thunnus thynnus & Thunnus albacares & MW714661 & MH638785 & ANGBF54814-19 & 99.39 \\
\hline PER1E [1] & Restaurant & tobiko/flying fish egg & Hirundichthys affinis ${ }^{\circ}$ & Hirundichthys affinis & MW714662 & JQ842898 & TOBA9086 & 99.35 \\
\hline PER2B [3] & Takeaway & sea bream or common bass & Sparus aurata/Dicentrarchus labrax & Dicentrarchus labrax & MW714663 & КР330301 & GBMIN94166-17 & 99.21 \\
\hline ORV1B [3] & Takeaway & common bass & Dicentrarchus labrax & Dicentrarchus labrax & MW714664 & KP330301 & GBMIN94166-17 & 98.58 \\
\hline ORV1T [2] & Takeaway & tuna & Thunnus thynnus & Thunnus albacares & MW714665 & MH638785 & ANGBF54814-19 & 98.17 \\
\hline ORV1E [3] & Takeaway & tobiko/flying fish egg & Hirundichthys affinis ${ }^{\circ}$ & Hirundichthys affinis & MW714666 & JQ842898 & TOBA086-09 & 99.52 \\
\hline ORV2B [3] & Restaurant & sea bream & Sparus aurata & Sparus aurata & MW714667 & KC501553 & DNATR1582-13 & 98.47 \\
\hline TER1B [3] & Takeaway & sea bream & Sparus aurata & Sparus aurata & MW714668 & КС501557 & DNATR1596-13 & 99.39 \\
\hline TER1T [3] & Takeaway & tuna & Thunnus thynnus & Thunnus orientalis & MW714669 & JN097817 & GBGCA1390-13 & 99.70 \\
\hline TER1E [3] & Takeaway & tobiko/flying fish egg & Hirundichthys affinis ${ }^{\circ}$ & Hirundichthys affinis & MW714670 & JQ842898 & TOBA9086 & 99.52 \\
\hline PE1B [3] & Restaurant & common bass & Dicentrarchus labrax & Dicentrarchus labrax & MW714671 & КР330301 & GBMIN94166-17 & 98.58 \\
\hline PE1T [3] & Restaurant & tuna & Thunnus thynnus & Thunnus albacares & MW714672 & MH638785 & ANGBF54814-19 & 98.92 \\
\hline PE1E [1] & Restaurant & tobiko/flying fish egg & Hirundichthys affinis ${ }^{\circ}$ & $\begin{array}{l}\text { Hirundichthys } \\
\text { coromandelensis }\end{array}$ & MW714673 & KX379460 & ANGBF32076-19 & 98.73 \\
\hline RO1T [3] & Restaurant & tuna & Thunnus thynnus & Thunnus albacares & MW714675 & HM007768 & ANGBF7098-12 & 99.39 \\
\hline RO1E [1] & Restaurant & tobiko/flying fish egg & Hirundichthys affinis ${ }^{\circ}$ & Mallotus villosus & MW714676 & FJ205579 & GBGC7486-09 & 99.23 \\
\hline
\end{tabular}

* FIR = Firenze; PER = Perugia; ORV = Orvieto; TER = Terni; PE = Pescara; RO = Roma ${ }^{\circ}{ }^{\circ}$ These species are not present in the Italian D.M. 2008 
Table 3. Sushi sampling in Southern Italy. In square brackets, the number of processed samples for each sushi product. In bold, misdescription cases.

\begin{tabular}{|c|c|c|c|c|c|c|c|c|}
\hline Code * & Retail Point & $\begin{array}{l}\text { Menu/Label } \\
\text { Description }\end{array}$ & $\begin{array}{c}\text { Scientific Name } \\
\text { of Declared Species }\end{array}$ & $\begin{array}{c}\text { Identified Species } \\
\text { by DNA } \\
\text { Barcoding and } \\
\text { BLAST Search }\end{array}$ & $\begin{array}{c}\text { GenBank Acc. } \\
\text { Number } \\
\text { of Obtained } \\
\text { Sequences }\end{array}$ & $\begin{array}{c}\text { Matched } \\
\text { GenBank } \\
\text { Accession from } \\
\text { BLAST }^{\circ}\end{array}$ & $\begin{array}{l}\text { Matched } \\
\text { BOLD ID }\end{array}$ & $\begin{array}{l}\% \text { Identity with } \\
100 \% \text { Coverage }\end{array}$ \\
\hline CAT1B [3] & Restaurant & sea bream or common bass & Sparus aurata & Sparus aurata & MW714949 & КС501553 & DNATR1582-13 & 99.08 \\
\hline CAT1T [3] & Restaurant & Tuna & Thunnus thynnus & Thunnus albacares & MW714950 & MH638785 & ANGBF54814-19 & 99.54 \\
\hline CAT1E [3] & Restaurant & tobiko/flying fish egg & Hirundichthys affinis ${ }^{\circ}$ & Mallotus villosus & MW714951 & FJ205579 & GBGC7486-09 & 99.39 \\
\hline CAT3B [3] & Restaurant & sea bream or common bass & Sparus aurata & Xiphias gladius & MW714952 & JN049558 & ANGBF7251-12 & 99.54 \\
\hline GE1B [3] & Restaurant & common bass & Dicentrarchus labrax & Dicentrarchus labrax & MW714953 & KP330301 & GBMIN94166-17 & 99.53 \\
\hline GE1T [3] & Restaurant & Tuna & Thunnus thynnus & Thunnus albacares & MW714954 & MH638785 & ANGBF54814-19 & 99.08 \\
\hline GE1E [3] & Restaurant & tobiko/flying fish egg & Hirundichthys affinis ${ }^{\circ}$ & Hirundichthys affinis & MW714955 & JQ842898 & TOBA086-09 & 99.52 \\
\hline GE2B [3] & Restaurant & common bass & Dicentrarchus labrax & Dicentrarchus labrax & MW714956 & KP330301 & GBMIN94166-17 & 99.53 \\
\hline ME1B [3] & Restaurant & sea bream & Sparus aurata & Sparus aurata & MW714957 & MF438138 & ANGBF45411-19 & 99.85 \\
\hline ME1T [3] & Restaurant & Tuna & Thunnus thynnus & Thunnus albacares & MW714958 & MH638762 & ANGBF54791-19 & 98.93 \\
\hline ME1E [3] & Restaurant & lumpfish roe & Cyclopterus lumpus & Cyclopterus lumpus & MW714959 & MG421634 & TZAIC166-05 & 99.54 \\
\hline ME2B [3] & Restaurant & sea bream & Sparus aurata & Sparus aurata & MW714960 & MF438138 & ANGBF45411-19 & 99.39 \\
\hline ME2E [2] & Restaurant & Ikura & salmon eggs & Oncorhynchus keta & MW714961 & LC094477 & ANGBF41103-19 & 98.93 \\
\hline $\mathrm{RC} 1 \mathrm{~B}[3]$ & Takeaway & Anago & Anguilla sp & Anguilla rostrata & MW714962 & KX459333 & SERCA165-12 & 98.31 \\
\hline RC1T [3] & Takeaway & Tuna & Thunnus thynnus & Thunnus albacares & MW714963 & MH638785 & ANGBF54814-19 & 99.39 \\
\hline RC1E [2] & Takeaway & Ikura & salmon eggs & Oncorhynchus keta & MW714964 & LC094477 & ANGBF41103-19 & 99.54 \\
\hline RC2E [2] & Takeaway & lumpfish roe & Cyclopterus lumpus & Cyclopterus lumpus & MW714965 & MG421634 & TZAIC166-05 & 99.07 \\
\hline LE1B [3] & Restaurant & sea bream & Sparus aurata & Sparus aurata & MW714966 & MF438138 & ANGBF45411-19 & 98.93 \\
\hline NA1B [3] & Takeaway & sea bream or common bass & Sparus aurata/Dicentrarchus labrax & Sparus aurata & MW714968 & KC501554 & DNATR1599-13 & 99.24 \\
\hline NA2B [3] & Takeaway & sea bream or common bass & Sparus aurata/Dicentrarchus labrax & Pomatomus saltatrix & MW714969 & KC501113 & DNATR1143-13 & 99.39 \\
\hline
\end{tabular}

${ }^{*} \mathrm{NA}=$ Napoli; $\mathrm{LE}=$ Lecce; RC = Reggio Calabria; ME = Messina; CAT = Catania; GE = Gela ${ }^{\circ}$ These species are not present in the Italian D.M. 2008 


\section{Results}

\subsection{Sampling}

A total of 61 sushi samples consisting of 45 fish samples, white fish and tuna, and 16 roe samples were collected from 15 restaurants and 14 takeaways from people living in 18 Italian cities who responded to the invitation to participate in the "sushi survey" (Figure 1). For each sushi venue, participants collected from 1 to 3 samples; in the latter case, "white fish", "tuna" and "fish roe" were sampled. The initial instructions provided by us to the participants in the survey allowed us to obtain a homogeneous, high-quality sampling plan throughout the territory. In Tables 1-3, the names found on the menu/label for each sample were reported, as well the corresponding scientific names of the declared species found in the list of the Italian names of fish species of commercial interest included in the Italian ministerial decree (MD) 21 September 2017. Misdescription was marked up when no match was found among the name on the menu, the scientific name in the list of the MD and the fish species identified by DNA barcoding.

\subsection{DNA Barcoding}

Three samples of each sushi product for a total of 180 samples were processed; however, DNA extraction was unsuccessful for 17 samples, and a total of 163 COI DNA sequences were obtained. The presence of multiple fish species was not detected after the COI sequencing of three samples for each examined product. The sequence length was between 636 and $655 \mathrm{bp}$. In these functional mitochondrial COI sequences, no insertions, deletions or stop codons were observed, and NUMTs were not sequenced given that vertebrate NUMTS are generally smaller than $600 \mathrm{bp}$ [59]. A total of 16 fish species were identified in all examined sushi products. The percent identity between the COI query sequences and their top-match sequences ranged from 98.17 to 99.85 with $100 \%$ of sequence coverage (Tables 1-3).

\subsection{Geographic Pattern of Sushi Product Misdescription}

\subsubsection{Northern Italy}

Red tuna, Thunnus thynnus, was substituted by yellowfin tuna, T. albacares, in three cases and by bigeye tuna, T. obesus, in one case; sea bream, Sparus aurata, was substituted in one case by yellowtail amberjack, Seriola lalandi. Concerning fish roe, only in one case, under the name tobiko or flying fish roe, the eggs of Mallotus villosus were found in place of the eggs of species of the genus Hirundichthys (Table 1).

\subsubsection{Central Italy}

In five cases, T. thynnus was substituted by T. albacares and in one case by T. orientalis, while tobiko or flying fish eggs were substituted by M. villosus eggs (Table 2).

\subsubsection{Southern Italy}

In all cases, red tuna, T. thynnus, was substituted by T. albacares. Sea bream was substituted in one case by Xiphias gladius and in another case by the bluefish, Pomatomus saltatrix. Tobiko or flying fish eggs in one case were substituted by the eggs of $M$. villosus.

Based on the names of the products chosen by consumers on the menu, a total of 17 species should have been detected, but we found a total of 29 species (Table 3).

\section{Discussion}

The results of the survey on the authentication of fish species used for sushi products sold in restaurants and takeaways in Italy indicate that a considerable rate of species substitution exists throughout the territory and that it is focused on certain species. The percentage of misdescription ranges from $31.8 \%$ in Northern Italy to $40 \%$ in Central Italy. The rate of misdescription affecting takeaways ranges from $25 \%$ of cases in Northern Italy to $50 \%$ in Southern Italy, while the percentage of misdescription in restaurants ranges from $33.3 \%$ in Southern Italy to $50 \%$ in Central Italy. The species most affected by replacement 
was Thunnus thynnus, which was substituted in $67 \%$ of cases in Northern Italy and $100 \%$ of cases in Central and Southern Italy. The so-called "white fish" usually represented by S. aurata and D. labrax was affected by a low rate of substitution ranging from $11 \%$ in Northern Italy to $22 \%$ in Southern Italy. Finally, tobiko or flying fish roe was affected by a medium rate of substitution ranging from $20 \%$ in Central Italy to $33 \%$ in Northern Italy. Before discussing our results, it should be noted that i) we compared them with those obtained from a similar survey carried out in Italy and in European and non-European countries, and ii) the cases of misdescription detected in the present study were based on the incongruence found between the scientific or common names of the species declared on the menu at the retailers (sushi restaurant and takeaway), the specific molecular diagnosis obtained through the COI DNA barcoding and the corresponding denomination in Italian language to be attributed to the detected fish species, as indicated in the decree of the Ministry of Agricultural, Food and Forestry Policies (MD n. 1910522 September 2017) dealing with the Italian names of fishes of commercial interest. In particular, the MD clearly states that to correctly inform consumers, the name to be used to indicate $T$. thynnus is "tuna" or "red tuna", while the name "yellowfin tuna" must be used to indicate T. albacares, and the names, "orientalis or oceanic tuna" and "bigeye tuna", should be used to indicate the species T. orientalis and T. obesus, respectively. Based on this premise, the high percentage of misdescription found for T. thynnus is shown by the fact that only in two cases out of 16 , consumers really ate red tuna as declared on the menu, while in $87.5 \%$ of cases, they consumed yellowfin tuna (12 cases), orientalis tuna (1 case) and bigeye tuna ( 1 case) in place of red tuna. The survey carried out in Italy by Armani et al. [54] on misdescription in sushi products sold in Tuscany revealed a generally low rate of misdescription (3.4\%), which in any case did not concern tuna-based products. However, the authors identified the products sold as tuna only at the genus level and then as belonging to the genus Thunnus, because EU regulations (1379/2013 and 1169/2011) require only the name of the seafood category and not the name of the species at the catering level. Similarly, a moderate level of species substitution (10\%) was detected by Vandamme et al. [11] during a screening of seafood labelling accuracy in sushi bars and restaurants across England. The low rate of substitution detected for tuna products was imputed to the United Kingdom labelling regulations allowing the inclusion of all Thunnus species under the umbrella term "tuna". Interestingly, high levels of mislabeling (83.3\%) for Bluefin tuna, T. thynnus, like those detected by us, were detected in French sushi restaurants, compared with the low general substitution rate (3.6\%) observed over the whole sampling [15]. An intermediate level of species substitution was detected by Oceana [60] in a survey carried out in sushi restaurants in Brussels, where a $54.5 \%$ level of fraud was found, mainly due to the frequent substitution of T. thynnus by others cheaper tropical tuna species (T. albacares and T. obesus). Both in the United States of America and in China, the species of the genus Thunnus are sold under the umbrella terms "tuna" according to the Food and Drug Administration and the Food and Drugs (Composition and Labelling) Regulations (Cap. 132W), respectively [50,61]. However, the molecular screening carried out by Lowenstein et al. [50] in the United States of America led to the identification of sushi tuna samples up to the level of species by highlighting the substitution of bluefin tuna by different species in $40 \%$ of samples. A case of the substitution of T. obesus by T. thinnus has also been observed in sushi products in Canada, which could raise suspicion of illegal, unreported and unregulated fishing issue [53]. Instead, the investigation carried out by However et al. [61] in Honk Kong stated that tuna samples, identified only at the genus level, were correctly labeled.

Focusing our attention on the other cases of species substitution observed in our study, three species, S. lalandi (Yellowtail amberjack named oceanic amberjack in the Italian list of the species), X. gladius (swordfish) and P. saltatrix (bluefish), were found in place of $S$. aurata declared on the menu. In this case, there is no doubt that the species substitution was deliberate, although the economic profit may not be the incentive to defraud, but rather the ease of finding the species. The Yellowtail amberjack is an aquaculture species often consumed as sashimi reared in Japan, Australia and New Zealand. In recent decades, 
the bluefish has undergone a rapid northern range expansion within the Mediterranean from the southern and eastern sectors of the basin. This geographical expansion has been demonstrated to be a result of increasing water temperature [62] and is having an important socio-economic impact due to the voracious behavior of this predator [63]. However, the presence of X. gladius in place of $S$. aurata is of major concern, as swordfish is a species of greater economic value than seabream, and in this case, substitution could launder illegally caught swordfish. Another frequent case of species substitution observed by us was the substitution of flying-fish eggs or tobiko by eggs of capelin, M. villosus. Flying fish are all included within the family Exocoetidae, and the term tobiko indicates the roe of flying fish of the genera Cheilopogon and Hyrundichthys generally used in sushi preparation. Tobiko is made of small eggs of $2 \mathrm{~mm}$ or less in size, which are crisp and of golden orange color. Due to the small supply of flying fish roe, tobiko are often prepared by using immature roe of capelin or other fish which might be also colored and sold as imitation [64,65]. The Italian MD n. 1910522 September 2017 includes the names of only two taxa of flying fish: the "oceanic flying-fish", which is an umbrella name for the species of Cypselurus spp., and "Indopacific flying-fish", which is used to indicate the species Cheilopogon atrisignis. Therefore, we considered only the above cases of substitution concerning M. villosus as misdescriptions, which was also reported by Armani et al. [54] in Tuscany and by Wallstrom et al. [66] in sushi bars in Honolulu. The results obtained from the molecular survey carried out in Italy indicate the effectiveness of COI barcoding for fish authentication in sushi products and highlight two main issues: (i) it is evident that a revision of the regulations by making the use of the scientific names of species mandatory for all products of the seafood supply chain is the only way to protect consumers from frauds, to guarantee their health, to protect the threatened species from illegal fishing and to restore the depleted fish stocks; (ii) to achieve these goals, a standardization of fish market names, avoiding using the same trade name to indicate multiple species, should be realized at the international level given that the fish market is now globalized.

Finally, the results of our study were obtained using the approach of Citizen Science, which allowed us to cover a wide portion of the Italian territory for the sushi survey. This relatively new approach was used by Bernard-Capelle et al. [15] to detect the rate of fish mislabeling in France and by Pardo et al. [67] to carry out a survey on seafood mislabeling in restaurants of 23 states across Europe. The most important benefit for researchers engaging citizens to obtain information for scientific investigations is the possibility to collect a high number of samples covering a wide geographical area controlling costs resulting from sampling. On the other hand, citizens, as consumers, will become aware of food safety concerns, which could be difficult to perceive by the end users of the food chain.

Supplementary Materials: The following are available online at https:/ /www.mdpi.com/article/10 .3390 /foods10040756/s1, Figure S1: sushi sampling guide.

Author Contributions: Conceptualization, A.M.P. and V.F.; methodology and experiments, A.M.P., A.R. and G.S.C.; data analysis, A.M.P. and V.F.; writing-original draft preparation, A.M.P. and V.F.; writing-review and editing, A.M.P. and V.F.; funding acquisition, V.F. All authors have read and agreed to the published version of the manuscript.

Funding: This research was funded by University of Catania, “PIA.CE.RI.” grant 2020.

Institutional Review Board Statement: Not applicable.

Informed Consent Statement: Not applicable.

Conflicts of Interest: The authors declare no conflict of interest.

\section{References}

1. Kim, N.H.; Yun, A.-R.; Rhee, M.S. Prevalence and classification of toxigenic Staphylococcus aureus isolated from refrigerated ready-to-eat foods (sushi, kimbab and California rolls) in Korea. J. Appl. Microbiol. 2011, 111, 1456-1464. [CrossRef] [PubMed]

2. Muscolino, D.; Giarratana, F.; Beninati, C.; Tornambene, A.; Panebianco, A.; Ziino, G. Hygienic-sanitary evaluation of sushi and sashimi sold in Messina and Catania, Italy. Ital. J. Food Saf. 2014, 3, 1701. [CrossRef] [PubMed] 
3. Liang, W.-L.; Pan, Y.-L.; Cheng, H.-L.; Li, T.-C.; Yu, P.H.-F.; Chan, S.-W. The microbiological quality of take-away raw salmon finger sushi sold in Hong Kong. Food Control 2016, 69, 45-50. [CrossRef]

4. Kulawik, P.; Dordevic, D.; Gambus, F.; Szczurowska, K.; Zajac, M. Heavy metal contamination, microbiological spoilage and biogenic amine content in sushi available on the Polish market. J. Sci. Food Agric. 2018, 98, 2809-2815. [CrossRef] [PubMed]

5. Guardone, L.; Armani, A.; Nucera, D.; Costanzo, F.; Mattiucci, S.; Bruschi, F. Human anisakiasis in Italy: A retrospective epidemiological study over two decades. Parasite 2018, 25, 41. [CrossRef]

6. $\quad$ Ramires, T.; Iglesias, M.A.; Vitola, H.S.; Nuncio, A.S.P.; Kroning, I.S.; Kleinubing, N.R.; Fiorentini, A.M.; da Silva, W.P. First report of Escherichia coli 0157:H7 in ready-to-eat sushi. J. Appl. Microbiol. 2019, 128, 301-309. [CrossRef]

7. Lehel, J.; Yaucat-Guendi, R.; Darnay, L.; Palotas, P.; Laczay, P. Possible food safety hazards of ready-to-eat raw fish containing product (sushi, sashimi). Crit Rev. Food Sci. Nutr. 2020. [CrossRef]

8. Hoel, S.; Mehli, L.; Bruheim, T.; Vadstein, O.; Jakobsen, A.N. Assessment of Microbiological Quality of Retail Fresh Sushi from Selected Sources in Norway. J. Food Prot. 2015, 78, 977-982. [CrossRef]

9. Lowenstein, J.H.; Burger, J.; Jeitner, C.W.; Amato, G.; Kolokotronis, S.-O.; Gochfeld, M. DNA barcodes reveal species-specific mercury levels in tuna sushi that pose a health risk to consumers. Biol. Lett. 2010, 6, 692-695. [CrossRef]

10. Burger, J.; Gochfeld, M.; Jeitner, C.; Donio, M.; Pittfield, T. Sushi consumption rates and mercury levels in sushi: Ethnic and demographic differences in exposure. J. Risk Res. 2014, 17, 981-997. [CrossRef]

11. Vandamme, S.G.; Griffiths, A.M.; Taylor, S.-A.; Di Muri, C.; Hankard, E.A.; Towne, J.A.; Watson, M.; Mariani, S. Sushi barcoding in the UK: Another kettle of fish. Peer] 2016, 4, e1891. [CrossRef]

12. House, J. Sushi in the United States, 1945-1970. Food Foodways 2018, 26, 40-62. [CrossRef]

13. EFSA (European Food Safety Authority). Scientific and technical assistance on the evaluation of the temperature to be applied to pre-packed fishery products at retail level. EFSA J. 2015, 13, 4162. [CrossRef]

14. US Food and Drug Administration. Protecting the Food Supply from Intentional Adulteration, Such as Acts of Terrorism. 2017. Available online: https:/ /www.fda.gov/Food/GuidanceRegulation/FSMA/ucm587803.htm (accessed on 24 January 2018).

15. Benard-Capelle, J.; Guillonneau, V.; Nouvian, C.; Fournier, N.; Le Loët, K.; Dettai, A. Fish mislabeling in France: Substitution rates and retail types. PeerJ 2015, 2, e714. [CrossRef]

16. Christiansen, H.; Dettai, A.; Heindler, F.M.; Collins, M.A.; Duhamel, G.; Hautecoeur, M.; Steinke, D.; Volckaert, A.M.; Van de Putte, A.P. Diversity of Mesopelagic fishes in the Southern Ocean-A phylogeographic perspective using DNA barcoding. Front. Ecol. Evol. 2018, 6, 120. [CrossRef]

17. Do, T.D.; Choi, T.J.; Kim, J.; An, H.E.; Park, Y.J.; Karagozlu, M.Z.; Kim, C.B. Assessment of marine fish mislabelling in South Korea's markets by DNA barcoding. Food Control 2019, 100, 53-57. [CrossRef]

18. Garcia-Vazquez, E.; Perez, J.; Martinez, J.L.; Pardiñas, A.F.; Lopez, B.; Karaiskou, N.; Triantafyllidis, A. High level of mislabelling in Spanish and Greek hake markets suggests the fraudulent introduction of African species. J. Agric. Food Chem. 2011, 59, 475-480. [CrossRef]

19. Rocco, L.; Ferrito, V.; Costagliola, D.; Marsilio, A.; Pappalardo, A.M.; Stingo, V.; Tigano, C. Genetic divergence among and within four Italian populations of Aphanius fasciatus (Teleostei, Cyprinodontiformes). Ital. J. Zool. 2007, 74, 371-379. [CrossRef]

20. Pappalardo, A.M.; Ferrito, V.; Messina, A.; Patarnello, T.; De Pinto, V.; Guarino, F.; Tigano, C. Genetic structure of the killifish Aphanius fasciatus Nardo 1827 (Teleostei, Cyprinodontidae), results of mitochondrial DNA analysis. J. Fish. Biol. 2008, 72, 1154-1173. [CrossRef]

21. Ferrito, V.; Pappalardo, A.M.; Canapa, A.; Barucca, M.; Doadrio, I.; Olmo, E.; Tigano, C. Mitochondrial phylogeography of the killifish Aphanius fasciatus (Teleostei, Cyprinodontidae) reveals highly divergent Mediterranean populations. Mar. Biol. 2013, 160, 3193-3208. [CrossRef]

22. Cuttitta, A.; Patti, B.; Maggio, T.; Quinci, E.M.; Pappalardo, A.M.; Ferrito, V.; De Pinto, V.; Torri, M.; Falco, F.; Nicosia, A.; et al. Larval population structure of Engraulis encrasicolus in the Strait of Sicily as revealed by morphometric and genetic analyses. Fish. Ocean 2015, 24, 135-149. [CrossRef]

23. Pappalardo, A.M.; Federico, C.; Sabella, G.; Saccone, S.; Ferrito, V. A COI nonsynonymous mutation as diagnostic tool for intraspecific discrimination in the European Anchovy Engraulis encrasicolus (Linnaeus). PLoS ONE 2015, 10, e0143297. [CrossRef]

24. Pedrosa-Gerasmio, I.R.; Agmata, A.B.; Santos, M.D. Genetic diversity, population genetic structure, and demographic history of Auxis thazard (Perciformes), Selar crumenophthalmus (Perciformes), Rastrelliger kanagurta (Perciformes) and Sardinella lemuru (Clupeiformes) in Sulu-Celebes Sea inferred by mitochondrial DNA sequences. Fish. Res. 2015, 162, 64-74.

25. Duong, T.; Uy, S.; Chheng, P.; So, N.; Thi Tran, T.; Nguyen, N.T.; Pomeroy, R.; Egna, H. Genetic diversity and structure of striped snakehead (Channa striata) in the Lower Mekong Basin: Implications for aquaculture and fisheries management. Fish. Res. 2019, 218, 166-173. [CrossRef]

26. Perea, S.; Al Amouri, M.; Gonzalez, E.G.; Alcaraz, L.; Yahyaoui, A.; Doadrio, I. Influence of historical and human factors on genetic structure and diversity patterns in peripheral populations: Implications for the conservation of Moroccan trout. bioRxiv 2020. [CrossRef]

27. Quinteiro, J.; Vidal, R.; Izquierdo, M.; Sotelo, C.G.; Chapela, M.J.; Pérez-Martín, R.I.; Rehbein, H.; Hold, G.L.; Russell, V.J.; Pryde, S.E.; et al. Identification of hake species (Merluccius genus) using sequencing and PCR-RFLP analysis of mitochondrial DNA control region sequences. J. Agric. Food Chem. 2001, 49, 5108-5114. [CrossRef] [PubMed] 
28. Kumar, G.; Kocour, M.; Kunal, S.P. Mitochondrial DNA variation and phylogenetic relationships among five tune species based on sequencing of D-loop region. Mitoch. DNA Part A 2016, 27, 1976-1980.

29. Ceruso, M.; Mascolo, C.; De Luca, P.; Venuti, I.; Smaldone, G.; Biffali, E.; Anastasio, A.; Pepe, T.; Sordino, P. A rapid method for the identification of fresh and processed Pagellus erythrinus species against frauds. Foods 2020, 9, 1397. [CrossRef] [PubMed]

30. Hebert, P.D.N.; Ratnasingham, S.; de Waard, J.R. Barcoding animal life: Cytochrome c oxidase subunit 1 divergence, among closely related species. Proc. R. Soc. Lond. B 2003, 270, S96-S99. [CrossRef]

31. Paquin, R.; Hedin, M. The power and perils of 'molecular taxonomy': A case study of eyeless and endangered Cicurina (Araneae: Dictynidae) from Texas caves. Mol. Ecol. 2004, 13, 3239-3255. [CrossRef]

32. Lefebure, T.; Douady, C.J.; Gouy, M.; Gibert, J. Relationship between morphological taxonomy and molecular divergence within Crustacea: Proposal of a molecular threshold to help species delimitation. Mol. Phyl. Evol. 2006, 40, 435-447. [CrossRef] [PubMed]

33. Vitale, D.G.M.; Viscuso, R.; D’Urso, V.; Gibilras, S.; Sardella, A.; Marletta, A.; Pappalardo, A.M. Morphostructural analysis of the male reproductive system and DNA barcoding in Balclutha brevis Lindberg 1954 (Homoptera, Cicadellidae). Micron 2015, 79, 36-45. [CrossRef]

34. Conti, E.; Mulder, C.; Pappalardo, A.M.; Ferrito, V.; Costa, G. How soil granulometry, temperature and water predict genetic differentiation in namibian Ariadna spiders and explain their behaviour. Ecol. Evol. 2019, 9, 4382-4391. [CrossRef] [PubMed]

35. Ward, R.D.; Zemlak, T.S.; Innes, B.H.; Last, P.R.; Hebert, P.D.N. DNA barcoding Australia's fish species. Philos. Trans. R. Soc. B 2005, 360, 1847-1857. [CrossRef] [PubMed]

36. Cutarelli, A.; Amoroso, M.G.; De Roma, A.; Girardi, S.; Galiero, G.; Guarino, A.; Corrado, F. Italian market fish species identification and commercial frauds revealing by DNA sequencing. Food Control 2014, 37, 46-50. [CrossRef]

37. Pappalardo, A.M.; Ferrito, V. DNA barcoding species identification unveils mislabeling of processed flatfish products in southern Italy markets. Fish. Res. 2015, 164, 153-158. [CrossRef]

38. Pappalardo, A.M.; Cuttitta, A.; Sardella, A.; Musco, M.; Maggio, T.; Patti, B.; Mazzola, S.; Ferrito, V. DNA barcoding and COI sequence variation in Mediterranean lanternfishes larvae. Hydrobiologia 2015, 745, 155-167. [CrossRef]

39. Pappalardo, A.M.; Copat, C.; Ferrito, V.; Grasso, A.; Ferrante, M. Heavy metal content and molecular species identification in canned tuna: Insights into human food safety. Mol. Med. Rep. 2017, 15, 3430-3437. [CrossRef]

40. Pappalardo, A.M.; Copat, C.; Raffa, A.; Rossitto, L.; Grasso, A.; Fiore, M.; Ferrante, M.; Ferrito, V. Fish-based baby food concern-From species authentication to exposure risk assessment. Molecules 2020, 25, 3961. [CrossRef]

41. Acutis, P.L.; Cambiotti, V.; Riina, M.V.; Meistro, S.; Maurella, C.; Massaro, M.; Stacchini, P.; Gili, S.; Malandra, R.; Pezzolato, M.; et al. Detection of fish species substitution frauds in Italy: A targeted national Monitoring plan. Food Control 2019, 101, 151-155. [CrossRef]

42. Pappalardo, A.M.; Ferrito, V. A COIBar-RFLP strategy for the rapid detection of Engraulis encrasicolus in processed anchovy products. Food Control 2015, 57, 385-392. [CrossRef]

43. Ferrito, V.; Bertolino, V.; Pappalardo, A.M. White fish authentication by COIBar-RFLP: Toward a common strategy for the rapid identification of species in convenience seafood. Food Control 2016, 70, 130-137. [CrossRef]

44. Pappalardo, A.M.; Federico, C.; Saccone, S.; Ferrito, V. Differential flatfish species detection by COIBar-RFLP in processed seafood products. Eur. Food Res. Technol. 2018, 244, 2191-2201. [CrossRef]

45. Pappalardo, A.M.; Petraccioli, A.; Capriglione, T.; Ferrito, V. From fish eggs to fish name: Caviar species discrimination by COIBar-RFLP, an efficient molecular approach to detect fraud in the caviar trade. Molecules 2019, 24, 2468. [CrossRef] [PubMed]

46. Ferrito, V.; Raffa, A.; Rossitto, L.; Federico, C.; Saccone, S.; Pappalardo, A.M. Swordfish or shark slice? A rapid response by COIBar-RFLP. Foods 2019, 8, 537. [CrossRef]

47. Yao, L.; Lu, J.; Qu, M.; Jiang, Y.; Li, F.; Guo, Y.; Wang, L.; Zhai, Y. Methodology and application of PCR-RFLP for species identification in tuna sashimi. Food Sci. Nutr. 2020, 8, 3138-3146. [CrossRef] [PubMed]

48. Xiong, X.; Yuan, F.; Huang, M.; Lu, L.; Xiong, X.; Wen, J. DNA Barcoding revealed mislabeling and potential health concerns with roasted fish products sold across China. J. Food Prot. 2019, 82, 1200-1209. [CrossRef]

49. Xiong, X.; Huang, M.; Xu, W.; Li, Y.; Cao, M.; Xiong, X. Using real time fluorescence loop-mediated isothermal amplification for rapid species authentication of Atlantic salmon (Salmo salar). J. Food Compos. Anal. 2021, 95, 103659. [CrossRef]

50. Lowenstein, J.H.; Amato, G.; Kolokotronis, S.O. The real maccoyii: Identifying tuna sushi with DNA barcodes-Contrasting characteristic attributes and genetic distances. PLoS ONE 2009, 4, e7866. [CrossRef]

51. Chin Chin, T.; Adibah, A.B.; Danial Hariz, Z.A.; Siti Azizah, M.N. Detection of mislabelled seafood products in Malaysia by DNA barcoding: Improving transparency in food market. Food Control 2016, 64, 247-256. [CrossRef]

52. Adibah, A.B.; Syazwan, S.; Haniza Hanim, M.Z.; Badrul Munir, M.Z.; Intan Faraha, A.G.; Siti Azizah, M.N. Evaluation of DNA barcoding to facilitate the authentication of processed fish products in the seafood industry. LWT-Food Sci. Technol. 2020, 129, 109585. [CrossRef]

53. Hu, Y.; Huang, S.Y.; Hanner, R.; Levin, J.; Lu, X. Study of fish products in Metro Vancouver using DNA barcoding methods reveals fraudulent labeling. Food Control 2018, 94, 38-47. [CrossRef]

54. Armani, A.; Tinacci, L.; Lorenzetti, R.; Benvenuti, A.; Susini, F.; Gasperetti, L.; Ricci, E.; Guarducci, M.; Guidi, A. Is raw better? A multiple DNA barcoding approach (full and mini) based on mitochondrial and nuclear markers reveals low rates of misdescription in sushi products sold on the Italian market. Food Control 2017, 79, 126-133. [CrossRef] 
55. Bonney, R.; Shirk, J.L.; Phillips, T.B.; Wiggins, A.; Ballard, H.L.; Miller-Rushing, A.J.; Parrish, J.K. Next Steps for Citizen Science. Science 2014, 343, 1436-1437. [CrossRef]

56. Kosmala, M.; Wiggins, A.; Swanson, A.; Simmons, B. Assessing Data Quality in Citizen Science. Front. Ecol. Environ. 2016, 14, 551-560. [CrossRef]

57. Ivanova, N.V.; Zemlak, T.S.; Hanner, R.H.; Hebert, P.D.N. Universal primer cocktails for fish DNA barcoding. Mol. Ecol. Notes 2007, 7, 544-548. [CrossRef]

58. Katoh, K.; Rozewicki, J.; Yamada, K.D. MAFFT online service: Multiple sequence alignment interactive sequence choice and visualization. Brief. Bioinform. 2019, 20, 1160-1166. [CrossRef] [PubMed]

59. Zhang, D.X.; Hewitt, G.M. Nuclear integrations: Challenges for mitochondrial DNA markers. Trends Ecol. Evol. 1996, 11, $247-251$. [CrossRef]

60. Oceana Europe 2015. Too Cheap to Be True, Seafood Fraud in Brussel. Available online: https://eu.oceana.org/sites/default/ files/421/oceana_factsheet_seafood_fraud_brussels_eng.pdf (accessed on 30 January 2021).

61. But, G.W.-C.; Wu, H.-Y.; Shaw, P.-C. Identification of fish species of sushi products in Hong Kong. Food Control 2019, 98, 164-173. [CrossRef]

62. Sabatés, A.; Martín, P.; Raya, V. Changes in life-history traits in relation to climate change: Bluefish (Pomatomus saltatrix) in the north-western Mediterranean. ICES J. Mar. Sci. 2012, 69, 1000-1009. [CrossRef]

63. Azzurro, E.; Cerri, J. The bluefish Pomatomus saltatrix (Pisces: Pomatomidae) in the Adriatic and Tyrrhenian Seas, can we call it climate invader? OSF Prepr. 2020. [CrossRef]

64. Bledsoe, G.E.; Bledsoe, C.D.; Rasco, B. Caviars and fish roe products. Crit. Rev. Food Sci. Nutr. 2003, 43, 317-356. [CrossRef] [PubMed]

65. Kokina, A.V.; Syromyatnikov, M.Y.; Savinkova, O.V.; Popov, V.N. The Use of DNA Barcoding and Metabarcoding for Food and Environment Quality Control. In Green Technologies and Infrastructure to Enhance Urban Ecosystem Services; Vasenev, V., Dovletyarova, E., Cheng, Z., Valentini, R., Calfapietra, C., Eds.; SSC 2018; Springer Geography Springer: Cham, Switzerland, 2020. [CrossRef]

66. Wallstrom, M.A.; Morris, K.A.; Carlson, L.V.; Marko, P.B. Seafood mislabeling in Honolulu, Hawai'i. Forensic Sci. Int. Rep. 2020, 2, 100154. [CrossRef]

67. Pardo, M.A.; Jimenez, E.; Viðarsson, J.R.; Olafsson, K.; Olafsdottir, G.; Daníelsdottir, A.K.; Perez-Villareal, B. DNA barcoding revealing mislabeling of seafood in European mass caterings. Food Control 2018, 92, 7-16. [CrossRef] 